術後は, 各臓器の動脈硬化性病変の合併をつねに念頭 に和きより適切な術後管理を要する。とくに破裂腹部 大動脈瘤では，ショックを経過して和り，急性腎不全準 備状態にあると考劣られ，決して脱水傾向に陷れてはな らない.

\section{結語}

破裂腹部大動脈瘤 6 例に緊急手術を施行し, 病院死は 2 例 (33\%) であった. 手術までの時間短縮, 全身の動
脈硬化性合併症に対する細やかな術後管理, 切迫破裂の 診断を含めた地域医療に対する啓蒙活動等により,さら に手術成績の向上に努めたい。

文 献 1) 稲田 洋ほか：日臨床外会誌 45:1659, 1984 . 2) Pasch, A.R. et al. : Circulation 70: Part 2, II-4, 1984. 3) Sheiner, N.M. : Can. J. Surg. $26: 523,1983$. 4) Rantakokko, V. et al. : Acta Chir. Scand. 149:151, 1983. 5) Soreide, O. et al. : Age Ageing, $11: 256,1982$. 6) Spirostein, W. : Surgery, $70: 744,1971$.

\title{
78 破裂腹部大動脈瘤の外科治療
}

\section{——くに術中死亡例の検討—}

\section{浜松医科大学 第 1 外科 \\ 原田幸雄竹下业山口貴司吉村敬三}

昭和 53 年 5 月から昭和 60 年 1 月までに手術を行った 腹部大動脈瘤は 15 例で破裂例は 6 例, うち 1 例は術 後 2 週目に誤嶼で急死し， 2 例を術中に失ったのでその要 因を検討した。

\section{症例}

破裂腹部大動脈瘤はすべて男性で腎下部の動脈硬化性 のもので術中死亡例以外を I 群, 術中死亡例を II 群とし た.すべて診断確定後ただちに手術室に運び開腹し， 3 例は横隔膜下で，3 例は腎下部で大動脈を遮断乙動脈瘤 を切開し I 群では瘤内に double velour knitted Dacron Y graft を用いて血行再建し，1例のみ左大腿動脈へ Gore-Tex graft による再建を追加した．Ｉ群の1例 (T.S.) は 78 歳で以前より狭心痛あり心マッサージ下に 開腹し大動脈を遮断したが血圧が維持できず死亡し, 剖 検により冠動脈狭窄を認めた.他の 1 例 (G.S.) は発症後 28 時間で手術を開始したが麻酔導入時に血圧下降し心 マッサージ下に開腹するもとの後 30 分で血清 $\mathrm{K}$ 值は $5.3 \mathrm{mEq} / l$ から $8.1 \mathrm{mEq} / l$ と急速に上昇し心停止とな り死亡した。

\section{結果}

i) 年齢 : I 群は 55〜75 歳 (平均 66.5 歳) であるが, II 群はともに 70 歳代 (平均 74.5 煘) であった. ii) 他 医からの搬送距離：I 群が $7 \sim 62 \mathrm{~km}$ (平均 $35.8 \mathrm{~km}$ ),
II 群は $7 \sim 37 \mathrm{~km}$ (平均 $22 \mathrm{~km}$ ) と II 群が短かった。 $\mathrm{iii)}$ 発症から手術までの時間：I 群は $4^{\circ} 30^{\prime} \sim 40^{\circ}$ (平均 $19^{\circ}$ 16') に対し, II 群は $13^{\circ} \sim 28^{\circ}$ (平均 $20^{\circ} 30^{\prime}$ ) と差はみ られない，iv）来院後大動脈遮断までの時間：I群は $70^{\prime} \sim 3^{\circ} 30^{\prime}$ (平均 $2^{\circ} 16^{\prime}$ ) に対し, II 群は $45^{\prime} \sim 90^{\prime}$ (平均 $\left.1^{\circ} 08^{\prime}\right)$ と状態の良いI群の汪らが長かった，v）来院時 血圧：I 群ではそれまでに収縮期圧 $75 \mathrm{mmHg}$ 以下のシ ョック状態となったが来院時には $100 \mathrm{mmHg}$ 以上に回 復していた．II群は $75 \mathrm{mmHg}$ と $100 \mathrm{mmHg}$ で来院し 手術までにさらに下降した。vi）術中出血量：I群

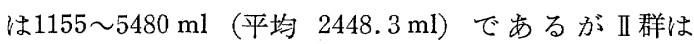
$3853 \mathrm{ml}$ と $4300 \mathrm{ml}$ (平均 $4076.5 \mathrm{ml}$ ) と多かった. vii）破裂の Type ${ }^{1)}$ ：I群はすべて closed type であった がII群は 2 例とも open type であった. viii) 術前心マ ッサージ：II群は 2 例とも心マッサージ下に執刀した (図 1,2).

\section{考察}

Hiatt $5^{2)}$ は破裂腹部大動脈瘤 29 例中術中死の 11 例を すべて出血死としているがその詳細は不明である，われ われの症例は出血性ショックを誘因とした心笳障害によ る死亡と, ショックや後腹膜血腫による血行障害に続く組 織の崩壞により急性腎不全となり保存血の大量輸血など が加わった血清 K值の急速な上昇が死因と考兄られた. これらの症例についての対策を考えると来院時すでに心 

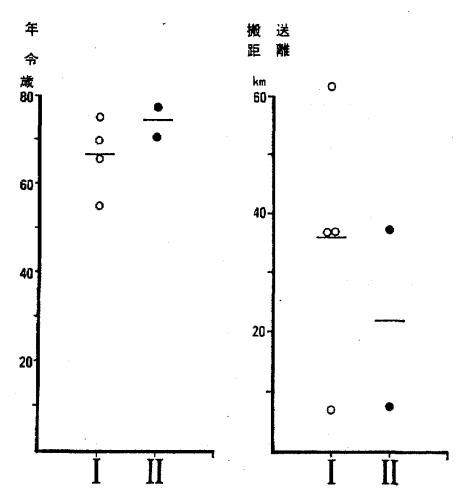

図 1
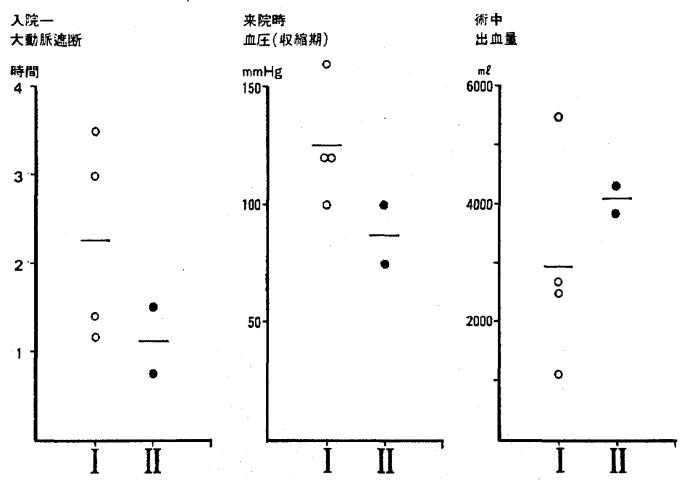

図 2

不全, 腎不全があり,しかも状態が急速に悪化している状 態ではそれらの治療を行ら時間的余裕はなく手術を行っ ても救命は困難である。これらの状態に至らぬ前に手術
表 1 腹部大動脈瘤破裂例 （浜医大 1 外）

\begin{tabular}{ccccc}
\hline & 年齢 & 性 & 高血圧 & 大動脈瘤自覚 \\
\hline I 群 & & & & \\
I.S. & 75 & $\mathrm{M}$ & + & + \\
Y.O. & 70 & $\mathrm{M}$ & + & - \\
Y.A. & 66 & $\mathrm{M}$ & + & - \\
T. S. & 55 & $\mathrm{M}$ & + & - \\
II 群 & & & & \\
G. S. & 71 & $\mathrm{M}$ & + & \pm \\
T.S. & 78 & $\mathrm{M}$ & + & - \\
\end{tabular}

を開始することが肝要である，われわれの 6 例中 5 例は 高血圧の治療を受けているが，I群の 1 例は 1 年前から 大動脈瘤を指摘されていて発症後 4 時間 30 分で手術が 始まっている．II 群の 1 例は降圧剤の投与を受けながら 本人は腹部腫瘤に気づいていたが大動脈瘤と指摘される ことなく破裂後 26 時間以上も経過してから来院し術中 血清 K值の上昇のため死亡した，発症前に大動脈瘤を自 覚しているか否かが予後に関係すると考方られる(表1).

\section{結 論}

破裂腹部大動脈瘤 6 例中 2 例を術中に失い 1 例は冠動 脈狭窄， 1 例は術中血清 $\mathrm{K}$ 值の著しい上昇を認めた。 2 例とも 70 歳以上で心マッサージ下に執刀し, open type で, 術中出血量 $3800 \mathrm{ml}$ 以上であった，発症以前に大 動脈瘤の診断をうけていた例は来院するのが早く病識の 有無が予後に関係するものと考えられる.

文 献 1) Szilagyi, D.E. et al.: Arch. Surg. $83: 395,1961$. 2) Hiatt, J.C.C. et al. : Arch. Surg. 119 : 1264, 1984. 